\title{
DESCRIPTIONS OF A NEW GENUS AND TWO NEW SPECIES
} OF AFRICAN FRESH-WATER CRABS.

\author{
By Mary J. Rathbun. \\ Aid, Department of Marine Invertebrates.
}

THE CRABS described below were found in mud under boards and timbers by Mr. J. H. Camp at Stanley Pool, Congo, West Central Africa.

Family THELPHUSID A.

PARATHELPHUSA CAMPI, new species.

Carapace subquadrilateral, conspicuously punctate. Depression between the gastric and cardiac regions deep. Protogastric lobes prominent, separated by a median groove which extends backward from the frontal margin. The postfrontal crest begins behind the base of the eyestalk and is continued to the lateral margin; it is finely denticulate and is almost straight, sloping backward and outward. Front a little more than one-third the width of the carapace, deflexed, divided by a very shallow sinus into two lobes, with a raised margin, which is continued to the postfrontal crest. Superior orbital margin sinuous, advanced in its middle portion. Postorbital tooth acute, prominent. Lateral branchial spines three. In one of the two specimens there is a spinule between the first and second spines, and a short fourth spine on the left side. Between the first spine and the postfrontal crest there are two or three spinules forming a short ridge in the same line with the postfrontal crest. From the last spine a raised line extends backward upon the carapace, and is followed by several broken parallel lines. The inferior margin of the orbit is rather deeply rounded below the outer angle; from that point the margin is directed inward and forward; the inner angle is obtuse; the margin is set with a row of bead-like granules. The terminal segment of the abdomen of the female is subtriangular, and the length is nearly half the width. The merus of the maxillipeds is very transverse, the antero-external angle rounded, the antero-internal angle not deeply cut.

Chelipeds of female unequal; merus rugose above, inner margin tuberculous, with a sharp spine just below the margin; carpus with two 
spines on the inner margin. Hand slightly inflated; upper margin straight, lower slightly convex. Fingers irregularly toothed and almost touching. Ambulatory legs rather slender, flattened; propodal joints indistinctly spinulous on the margins.

Measurements.-(No. 18065, two females). Length of larger specimen, $21.5 \mathrm{~mm}$.; width, 29.5. Length of smaller specimen, 19; width, 27 .

This species, in its three lateral teeth, resembles $P$. pacilei, A. Milne-Edwards, but differs from that species in its narrower and more quadrate carapace and interrupted postfrontal crest.

\section{ERIMETOPUS, new genus.}

Carapace arcuate anteriorly, quadrate posteriorly, moderately convex. Front advanced beyond the antennular cavities, composed of two distinct rounded lobes. Orbits narrow; eye-stalks tapering to the extremity. Postfrontal erest short and inconspicuous, or wanting. Lateral margins spinous. The merus of the maxillipeds is transverse, the antero-external angde rounded, the palpus articulating at the internal angle, which is very slightly notched. Chelipeds with a row of spines on the anterior margin of the carpus. Ambulatory legs with margins spinous.

ERIMETOPUS SPINOSUS, new species.

Carapace about four-fifths as long as broad, convex longitudinally, postero-lateral margins long, sloping slightly inward and backward, antero-lateral margins arcuate. The cardiac region and the posterior portion of the gastric region are outlined by shallow depressions. Front about one-third the width of the carapace, advanced, two-lobed, lobes separated by a broad V shaped sinus. Margin of front and orbits granulous. Orbits well-defined, the outer angle a sharp incurved spine. There are two protogastric lobes, little elevated and often not discernible, except by two transverse lines of a lighter color. A very shallow median groove extends backward from the frontal margin and forks directly behind the protogastric lobes. The postfrontal crest, when present, is short, areuate, tuberculous, and indistinct. It begins back of the cornea and for a short distance is nearly straight, directed outward and slightly forward, then curves almost parallel to the antero. lateral margin. In most specimens, however, the crest is obsolete. indicated only by the smoothly-rounded elevation behind the orbit, Antero-lateral margin with a row of from 5 to 8 spines next the orbit, of which the orbital spine is the largest. The spines are irregular in size and position. On the anterior branchial region are 5 or more marginal spines separated by a space from the hepatic spines; the anterior is by far the larger, and is sometimes bifid. The others decrease in length posteriorly. The suborbital margin is granulous except at the notch beneath the postorbital spine. The abdomen of the female covers the sternum. 
Chelipeds in the female unequal. The margins of the merus are spinulous, the upper margin with a sharp spine near the carpus, the inner surface tuberculous at its base, the lower surface with a transverse tuberculous ridge at its distal end. The carpus has two strong spines on its inner margin, and a row of about 7 smaller spines on the anterior margin, two of which are close to the condyle of the manus and are separated by a wide interval from the remaining spines. Sometimes one of the spines is bifid, and occasionally additional spinules oceur on the upper surface behind the marginal spines. The manus is slightly swollen, with a convex lower margin and almost straight upper margin, which sometimes in the smaller cheliped has a small sharp spine at the distal end; in a few specimens there are one or two spines at the proximal end. Fingers irregularly dentate on their prehensile edges and slightly gaping. The ambulatory legs are rather broad, flattened; meral joints with two spines at the distal end; carpal and propodal joints strongly spined above; carpal joints with distal spines in the first pair and often in the second and third pairs; propodal joints with a few spines below; dactyli with four rows of spines.

Measurements.-(No. 18066, female.) Length, $30.5 \mathrm{~mm}$.; greatest width, 38 ; width between postorbital spines, 19 .

The male is unknown.

This species can be distinguished from other Thelphusidæ by its produced, round-lobed front, narrow orbits, and numerous spines. 


\section{$2 \mathrm{BHL}$ Biodiversity Heritage Library}

Rathbun, Mary Jane. 1894. "Descriptions of a new genus and two new species of African fresh-watercrabs." Proceedings of the United States National Museum 17(980), 25-27. https://doi.org/10.5479/si.00963801.980.25.

View This Item Online: https://www.biodiversitylibrary.org/item/53454

DOI: https://doi.org/10.5479/si.00963801.980.25

Permalink: https://www.biodiversitylibrary.org/partpdf/52118

\section{Holding Institution}

Smithsonian Libraries

\section{Sponsored by}

Smithsonian

\section{Copyright \& Reuse}

Copyright Status: Public domain. The BHL considers that this work is no longer under copyright protection.

This document was created from content at the Biodiversity Heritage Library, the world's largest open access digital library for biodiversity literature and archives. Visit BHL at https://www.biodiversitylibrary.org. 